\title{
Pengaruh Perubahan Ketebalan Terhadap Tegangan Ambang Dan Waktu Tanggap Pada Sel Twisted Nematic
}

\section{Linus Setyo Adhidhuto, Yusril Yusuf}

Jurusan Fisika, Fakultas Matematika dan Ilmu Pengetahuan Alam, Universitas Gadjah Mada Sekip Utara PO BOX BLS 21 Yogyakarta Indonesia 55281

Linus_s_a@mail.ugm.ac.id

\begin{abstract}
Abstrak - Telah dilakukan penelitian pengaruh ketebalan sel kristal cair terhadap tegangan ambang serta waktu tanggap untuk sel Twisted Nematic (TN). Digunakan 4 sel TN dengan ketebalan berbeda $50 \mu m, 100 \mu m, 150 \mu m$, dan $200 \mu m$, yang masing-masing diisi dengan kristal cair jenis 4-n-pentyl-4'-cyanobiphenyl (5CB). Ketebalan sel tidak mempengaruhi tegangan ambang, namun mempengaruhi waktu tanggap. Waktu tanggap yang diteliti ada 2 jenis yaitu rise time dan fall time. Semakin tebal sel TN, maka semakin besar pula rise time dan fall time.
\end{abstract}

Kata kunci: sel twisted nematic, tegangan ambang, waktu tanggap

Abstract - Influence of thickness changes of threshold voltage and response time in twisted nematic cell has been studied. Four twisted nematic cells which filled with 4-n-pentyl-4'-cyanobiphenyl (5CB) with different thickness, that are 50 um, 100 $\mu \mathrm{m}, 150 \mu \mathrm{m}$, and $200 \mu \mathrm{m}$, has been used. The thickness of the cell didn't affect threshold voltage, but highly affect the response time. There are 2 kind of response time which observed in this research : rise time and fall time. As the thickness of the cell increase, rise time and fall time will increase too.

Key words: twisted nematic cell, threshold voltage, response time

\section{PENDAHULUAN}

Hingga akhir 1990-an, teknologi layar didominasi oleh monitor CRT (Chatode Ray Tube). Televisi, monitor komputer, dan berbagai macam media lainnya masih menggunakan teknologi CRT. Namun pada awal 2000 an, monitor CRT ini mulai ditinggalkan. Ukurannya yang besar dinilai sangat tidak praktis. Besarnya daya yang dibutuhkan serta bahaya radiasi yang dikeluarkan menambah daftar panjang alasan untuk tidak menggunakan teknologi ini lagi. Berbagai macam penelitian telah dilakukan sejak dulu untuk mendapatkan monitor pengganti yang lebih baik. Hingga akhirnya ditemukan teknologi LCD (liquid crystal display). Sejak dilakukan penelitian dari tahun 1970 an, teknologi LCD yang lebih tipis, ringan dan lebih hemat energi ini berkembang pesat dan mulai menggantikan monitor CRT. Pada tahun 2007, untuk pertama kalinya penjualan LCD melebihi monitor CRT [2].

Pada penelitian ini akan dicari pengaruh ketebalan sel TN terhadap tegangan ambang dan waktu tanggapnya. Digunakan 4 buah sel TN dengan ketebalan masing-masing $50 \mu \mathrm{m}, 100 \mu \mathrm{m}, 150 \mu \mathrm{m}$, dan $200 \mu \mathrm{m}$.

\section{LANDASAN TEORI}

Transmisi cahaya pada sel TN sebagai fungsi tegangan ditunjukkan pada grafik di gambar 1. Ketika tegangan yang diberikan pada elektroda kurang dari tegangan ambang (threshold voltage), tidak ada perubahan pada transmisi cahaya. Bila tegangan dinaikkan hingga mendekati tegangan ambang, transmisi cahaya mulai turun. Transmisi cahaya akan terus menurun secara drastis bila tegangan terus dinaikkan hingga akhirnya besarnya tegangan mencapai tegangan saturasi (saturation voltage). Setelah tegangan dinaikkan melebihi tegangan saturasi ini, penurunan transmisi cahaya mulai berkurang hingga akhirnya tidak terjadi penurunan transmisi cahaya lagi [1].

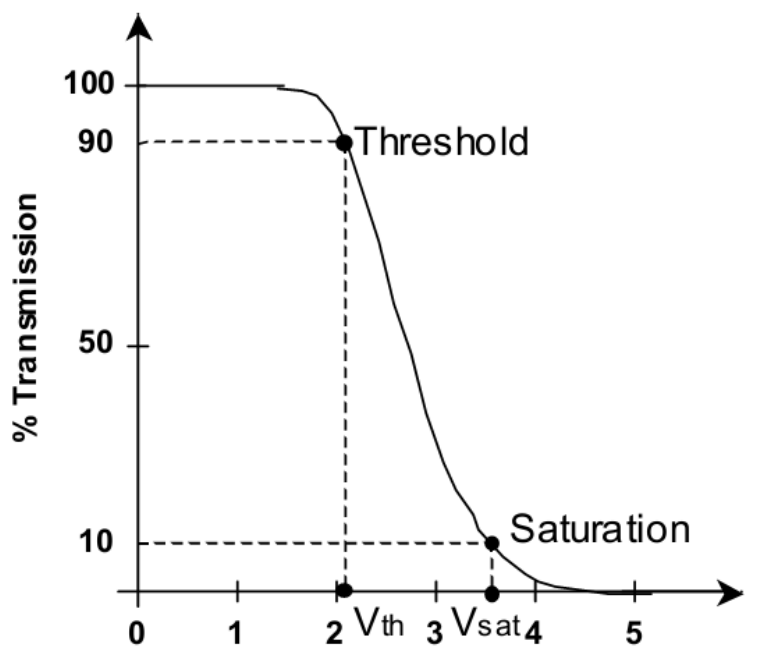

Gambar 1. Efek elektro-optik pada sel TN normal yang menunjukkan transmisi cahaya sebagai fungsi tegangan pada frekuensi $1 \mathrm{kHz}[1]$

Tegangan saturasi diperoleh ketika transmisi cahaya $10 \%$, sedangkan tegangan ambang ketika transmisi cahaya 
90\%. Tegangan ambang $\left(V_{t h}\right)$ ini ditentukan dengan persamaan (1) [3].

$$
V_{t h}=\pi \sqrt{\frac{k_{11}+\frac{k_{33}-2 k_{22}}{4}}{\left|\Delta \varepsilon \cdot \varepsilon_{0}\right|}}
$$

Dari persamaan tersebut, bisa diketahui bahwa tegangan ambang ini dipengaruhi oleh tetapan dielektrik anisotropi serta konstanta elastik kristal cair.

Salah satu parameter yang menyatakan baik tidaknya suatu LCD yaitu waktu tanggap. Waktu tanggap ditentukan dalam tiga parameter yaitu delay time, rise time, dan fall time. Fall time $\left(t_{f}\right)$ yaitu waktu yang dibutuhkan untuk menaikkan transmisi cahaya dari $10 \%$ ke $90 \%$. Sedangkan rise time $\left(t_{r}\right)$ adalah waktu yang diperlukan untuk menurunkan transmisi cahaya dari $90 \%$ ke $10 \%$. Delay time me rupakan waktu yang diperlukan untuk merubah transmisi cahaya dari $0 \%$ ke 10\% (fall) atau 100\% ke 90\% (rise).

Rise time dan fall time untuk sel TN dirumuskan pada persamaan (2) dan (3) [1].

$$
\begin{array}{r}
t_{r}=\frac{\gamma d^{2}}{\varepsilon_{0} \Delta \varepsilon V^{2}-\pi^{2} k_{E Q}} \\
(2) \\
t_{f}=\frac{\gamma d^{2}}{\pi^{2} k_{E Q}}
\end{array}
$$

Dimana $\gamma$ merupakan koefisien viskositas rotasi, $\Delta \varepsilon$ adalah konstanta dielektrik anisotropi, $k_{E Q}$ nilai rata-rata konstanta elastik kristal cair dan $V$ merupakan tegangan.

Rise time dan fall time secara umum tergambar dalam grafik pada gambar 2. Namun dalam beberapa kasus, grafik yang muncul tidak langsung turun atau naik, melainkan mengalami fluktuasi tergantung ketebalan sel TN.

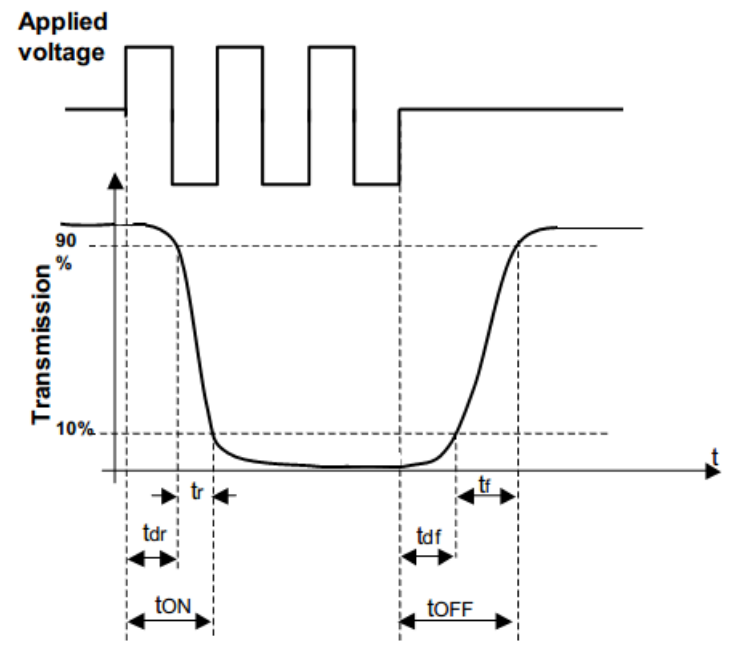

Gambar 2. Grafik waktu tanggap sel TN [1]

\section{METODE PENELITIAN/EKSPERIMEN}

Untuk mengamati efek elektro-optik pada sel TN, gambar sel TN diambil menggunakan kamera CCD yang terpasang pada mikroskop. Gambar yang diambil oleh kamera CCD ditampilkan dan disimpan pada komputer. Pada penelitian ini digunakan 4 sel $\mathrm{TN}$ berbahan dasar 5CB ("4-cyano-4'-n-pentyl-biphenyl") dengan ketebalan 50 $\mu \mathrm{m}, 100 \mu \mathrm{m}, 150 \mu \mathrm{m}$, dan $200 \mu \mathrm{m}$.

\section{A. Pengukuran Tegangan Ambang}

Untuk pengukuran tegangan ambang sel $\mathrm{TN}$, sampel diberikan tegangan yang bervariasi dari 0 volt sampai 17 volt dengan interval 0,5 volt. Dari data yang diperoleh, bisa didapatkan nilai tegangan ambang dan tegangan saturasi dari sampel. Data-data tersebut diolah kedalam bentuk grafik menggunakan program Kaleida Graph. Variabel pada sumbu- $x$ merupakan tegangan yang diberikan pada sampel dengan satuan volt. Pada sumbu- $y$, variabel yang digunakan yaitu nilai intensitas cahaya yang sudah dinormalisasi dengan intensitas sel TN sebelum diberi tegangan $\left(I / I_{0}\right)$. Pada nilai tegangan yang cukup besar, akan terjadi penurunan intensitas cahaya yang sangat drastis. Bila besar tegangan mencapai tegangan saturasi sampel tersebut, penurunan intensitas cahaya akan berhenti dan intensitas cahaya akan stabil pada nilai tertentu. Tegangan ambang atau threshold voltage $\left(V_{t h}\right)$ berada pada $90 \% \mathrm{I} / \mathrm{I}_{0}$, sedangkan tegangan saturasi berada pada $10 \% I / I_{0}$.

\section{B. Pengukuran Waktu Tanggap}

Pada pengukuran waktu tanggap, akan diukur fall time dan rise time sel TN. Untuk pengukuran rise time sel TN diberikan tegangan yang besar (melebihi tegangan saturasi) agar sel TN menjadi gelap. Saklar yang menghubungkan synthesizer dengan sampel dimatikan sehingga sel sampel belum menerima tegangan. Setelah itu saklar dinyalakan dan video sampel direkam menggunakan komputer yang terhubung dengan kamera CCD.

Untuk pengukuran fall time, mula-mula sel TN sudah diberikan tegangan yang besar (melebihi tegangan saturasi). Saklar kemudian dimatikan dan video sampel direkam melalui komputer.

Video-video yang diperoleh ini kemudian dianalisis intensitas cahayanya menggunakan program ImageJ. Selanjutnya akan diperoleh data intensitas cahaya terhadap waktu. Data ini kemudian diolah menjadi grafik mengunakan program Kaleida Graph. Variabel sumbu- $x$ merupakan waktu dengan satuan sekon dan sumbu-y merupakan nilai normalisasi intensitas dengan intensitas sebelum diberi medan listrik. Dari grafik ini bisa diperoleh besarnya rise time dan fall time.

\section{HASIL DAN PEMBAHASAN}

A. Pengukuran Intensitas Cahaya Yang Menembus Sel TN Dengan Ketebalan Berbeda

Data tegangan ambang yang diperoleh ditunjukkan oleh grafik pada gambar 3. Untuk sampel dengan ketebalan 50 $\mu m$, tegangan ambang berada pada nilai 6,91 volt. Pada 
sampel dengan ketebalan $100 \mu \mathrm{m}$, intensitas cahaya menurun drastis setelah tegangan melewati tegangan ambang yaitu sebesar 7,67 volt. Sampel dengan ketebalan $150 \mu \mathrm{m}$ memiliki tegangan ambang sebesar 7,08 volt, sedangkan pada sampel $200 \mu \mathrm{m}$ diperoleh tegangan ambang sebesar 6,83 volt.

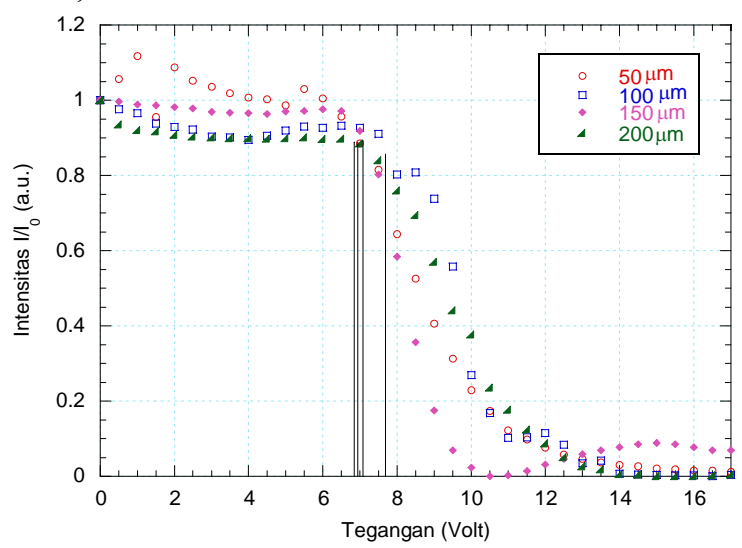

Gambar 3. Grafik hubungan antara intensitas cahaya dengan tegangan pada sel TN

Jika dibandingkan antara keempat sampel seperti diperlihatkan pada gambar 4 , tegangan ambang berada pada kisaran nilai yang sama yaitu sekitar 7 volt. Hal ini sesuai dengan teori dimana nilai tegangan ambang tidak tergantung pada ketebalan sampel. Pada persamaan (1) terlihat bahwa yang mempengaruhi tegangan ambang yaitu modulus elastisitas dan tetapan dielektrik bahan. Jadi bila bahan yang digunakan sama, maka nilai tegangan ambang akan sama pula.

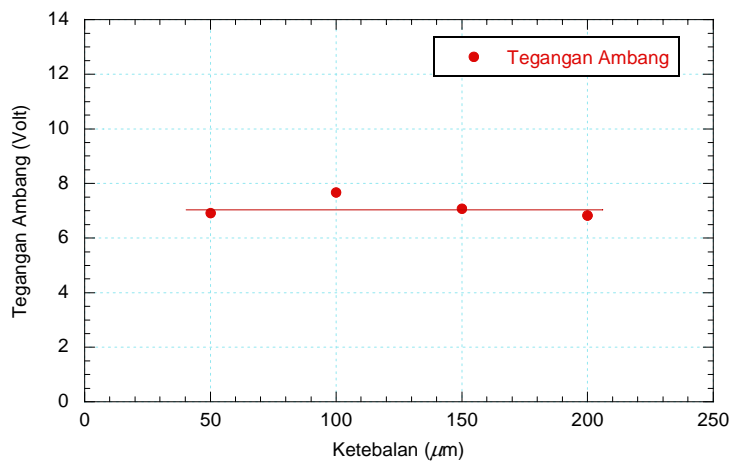

Gambar 4. Grafik hubungan antara tegangan ambang dengan ketebalan sel TN

\section{B. Pengukuran Waktu Tanggap Sel TN Dengan Ketebalan Berbeda}

Setelah dilakukan pengamatan rise time, diperoleh data dalam bentuk grafik pada gambar 5.a. Untuk sampel dengan ketebalan $50 \mu \mathrm{m}$, diperoleh rise time sebesar 4,55 sekon. Pada ketebalan $100 \mu \mathrm{m}$, diperoleh waktu yang lebih lama yaitu 5,28 sekon, dan pada sampel $150 \mu \mathrm{m}$ diperlukan waktu 6,32 sekon untuk berubah dari intensitas $90 \%$ ke $10 \%$. Namun pada ketebalan $200 \mu \mathrm{m}$, rise time yang diperoleh hanya sedikit lebih besar daripada sampel $150 \mu \mathrm{m}$ yaitu sebesar 6,49 sekon.
Hasil pengukuran fall time digambarkan dalam bentuk grafik pada gambar 5.b. Dari grafik tersebut terlihat intensitas cahaya tidak langsung meningkat menuju intensitas awal, namun sempat mengalami beberapa kali

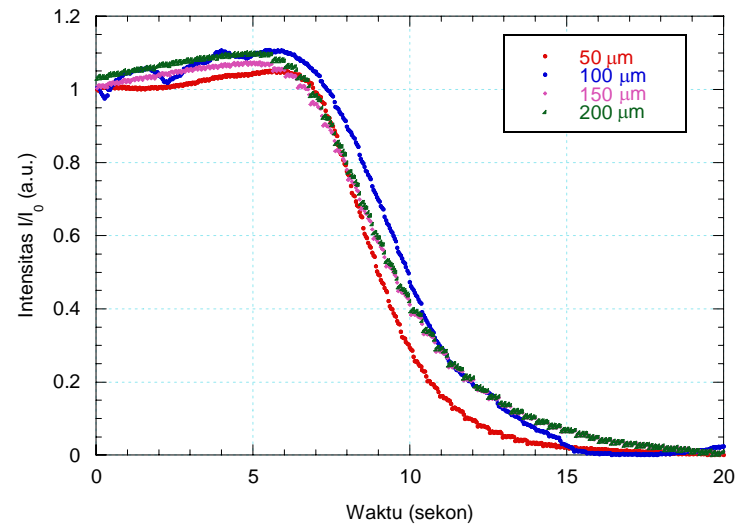

(a) Keadaan ON

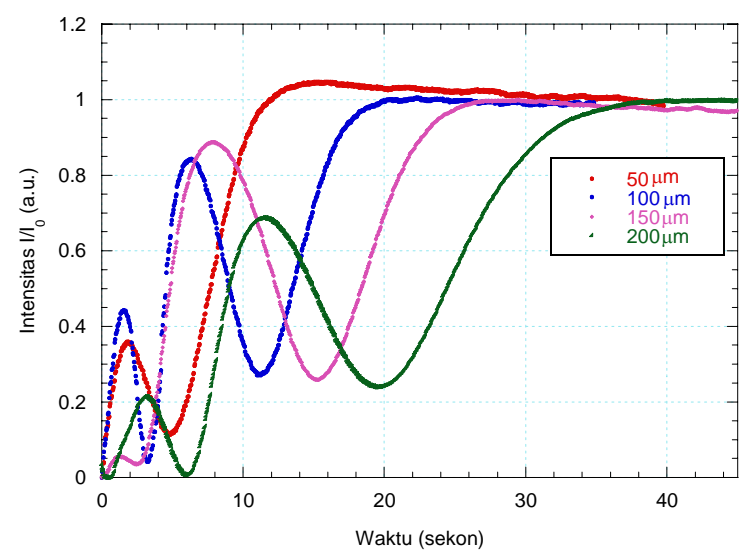

(b) Keadaan OFF

Gambar 5. Grafik perubahan intensitas cahaya terhadap waktu ketika (a) sel TN diberi medan listrik (keadaan ON), dan (b) medan listrik pada sel TN dihilangkan (keadaan OFF)

naik turun. Pada sel dengan ketebalan $50 \mu \mathrm{m}$, puncak pertama berada pada waktu 1,89 sekon dan kemudian mengalami turun serta naik lagi hingga mencapai $90 \%$ intensitas setelah menempuh total waktu 10,33 sekon.

Berbeda dengan sampel $50 \mu \mathrm{m}$, ketiga sampel lainnya memiliki 3 puncak. Pada sel $100 \mu \mathrm{m}$, puncak pertama dengan intensitas sekitar $0,55 \mathrm{I} / \mathrm{I}_{0}$ ditempuh dalam waktu 1,52 sekon. Puncak kedua ditempuh dalam waktu 6,17 sekon dengan intensitas mendekati $0,88 \mathrm{I} / \mathrm{I}_{0}$. Intensitas $90 \%$ ditempuh dalam total waktu 16,51 sekon. Pada sampel 150 $\mu \mathrm{m}$, puncak pertama ditempuh dalam waktu 1,26 sekon dengan intensitas puncak $0,31 \quad I / I_{0}$. Puncak selanjutnya dengan intensitas puncak $0,91 \quad I / I_{0}$ ditempuh setelah 7,93 sekon. Intensitas $90 \%$ ditempuh setelah 22,67 sekon. Puncak pertama sel TN dengan ketebalan $200 \mu \mathrm{m}$ ditempuh dalam waktu 3,27 sekon dengan intensitas puncak sekitar 0,4 I/I . Puncak kedua ditempuh dalam waktu 11,59 sekon dengan 
intensitas puncak sekitar $0,77 I / I_{0}$ dan intensitas $90 \%$ pada puncak ketiga ditempuh setelah 31,61 sekon.

Munculnya gelombang-gelombang pada kurva fall time terjadi karena sel TN sangat tebal. Ketika medan listrik! berhenti diberikan, tidak semua molekul terkena restoring force (gaya untuk kembali ke posisi awal) yang sama besarnya. Molekul yang dekat dengan plat kaca terkena gaya yang lebih kuat dibandingkan dengan molekul di tengah sel sehingga bisa kembali ke posisi awal dengan lebih cepat. Oleh karena itu bila sel TN yang digunakan semakin tebal, maka akan semakin banyak gelombang yang muncul.

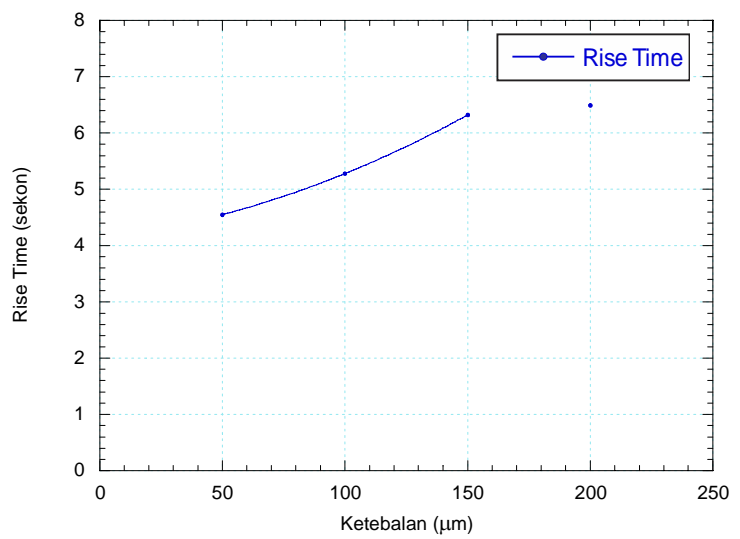

(a) Rise Time

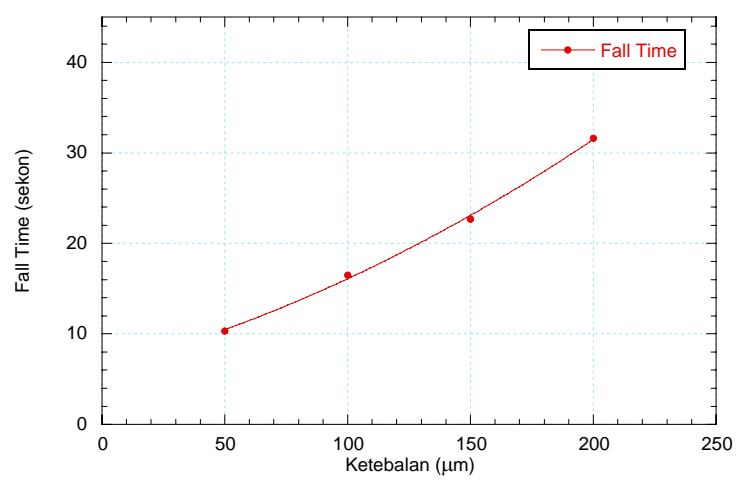

(b) Fall Time

Gambar 6. Grafik hubungan antara (a) rise time dengan ketebalan sel TN dan (b) fall time dengan ketebalan sel TN.

Dari hasil pengamatan rise time, semakin tebal sampel maka semakin besar pula rise time sel TN tersebut. Menurut persamaan (2), perubahan rise time terhadap ketebalan sampel membentuk kurva kuadrat positif. Namun dari keempat data yang diperoleh terbentuk kurva kuadrat negatif. Data rise time untuk sel TN dengan ketebalan $200 \mu \mathrm{m}$ mengalami sedikit penyimpangan dari prediksi teori (persamaan 2) saat tegangan ON. Namun ketika tegangan OFF, data fall time untuk sel ini kembali sesuai dengan prediksi teori (persamaan 3). Hal ini memperlihatkan bahwa untuk sel yang relatif tebal maka eksperimen pengukuran rise time perlu perlakuan khusus.

Garis pada gambar 6.a adalah kurva fitting untuk rise time sebagai fungsi ketebalan tanpa melibatkan data untuk
TN dengan ketebalan $200 \mu m$. Fungsi garis pada gambar 6.a adalah

$$
t_{r}=\left(6,2 \times 10^{-5}\right) d^{2}+0,005 d+4,13
$$

dimana $t_{r}$ adalah rise time dan $d$ adalah ketebalan sel TN.

Tidak seperti rise time, grafik hubungan antara fall time dengan ketebalan sel TN pada keempat sampel terbentuk kurva kuadrat positif. Persamaan kurva tersebut dituliskan dalam persamaan (5).

$$
t_{f}=\left(2,76 \times 10^{-4}\right) d^{2}+0,071 d+6,23
$$

dimana $t_{f}$ adalah fall time dan $d$ merupakan ketebalan sel TN. Sama seperti rise time, pada keadaan OFF semakin tebal sel $\mathrm{TN}$ maka semakin lama fall time.

LCD pada umumnya memiliki rise time yang berkisar antara $10-50 \mathrm{~ms}$, jauh lebih kecil jika dibandingkan dengan rise time dari hasil percobaan. Hal ini disebabkan sel TN yang digunakan dalam penelitian tidak ideal dimana dibuat sendiri di laboratorium. Hal yang sama juga terjadi pada fall time dimana fall time hasil percobaan mencapai puluhan sekon.

\section{KESIMPULAN}

Dari hasil penelitian yang telah dilakukan terhadap 4 sel TN dengan ketebalan berbeda, dapat disimpulkan

1. Telah berhasil dibuat 4 sel Twisted Nematic dalam skala laboratorium dengan luas sel $2,5 \mathrm{~cm} \times 2 \mathrm{~cm}$ dan ketebalan masing-masing $50 \mu \mathrm{m}, 100 \mu \mathrm{m}, 150 \mu \mathrm{m}$, dan $200 \mu \mathrm{m}$. Ketebalan sel ini memiliki pengaruh yang berbeda-beda untuk tiap-tiap efek elektro optik.

2. Ketebalan sel TN tidak mempengaruhi tegangan ambang dari sel tersebut. Dari pengukuran keempat sampel diperoleh nilai tegangan ambang yang berada pada 7 Volt. Namun ketebalan sel TN sangat berpengaruh pada waktu tanggap. Semakin tebal sel TN maka semakin lama pula waktu tanggapnya. Untuk pengamatan rise time, data sel TN dengan ketebalan $200 \mu \mathrm{m}$ tidak dilibatkan karena menyimpang dari prediksi teori. Hal ini memperlihatkan bahwa sampel yang baik untuk TN adalah sampel yang tipis misalnya lebih kecil dari 200 $\mu \mathrm{m}$. Hubungan antara ketebalan sel TN $(d)$ dengan rise time $\left(t_{r}\right)$ yaitu

$t_{r}=\left(6,2 \times 10^{-5}\right) d^{2}+0,005 d+4,13 ;$

sedangkan hubungan antara ketebalan sel TN $(d)$ dengan fall time $\left(t_{f}\right)$ yaitu

$$
t_{f}=\left(2,76 \times 10^{-4}\right) d^{2}+0,071 d+6,23
$$

\section{UCAPAN TERIMA KASIH}

Terima kasih kepada DIKTI karena telah mendanai penelitian ini melalui Hibah Kompetisi DIKTI.

\section{PUSTAKA}

[1] Cristaldi, D.J.R., Pulvirenti, F., Pennisi, S., 2009, Liquid Crystal Display Drivers : Techniques and Circuits, Springer Science, Catania. 
[2] Gruener, Wolfgang, 2008, LCD TVs Outship CRT TVs for The First Time, http://www.tgdaily.com/business-and-lawfeatures/36119-lcd-tvs-outship-crt-tvs-for-the-first-time

[3] Sarma, K.R., 2000, Liquid Crystal Displays, CRC Press LLC 